Atouts et outils de l'ethnologie des techniques

\title{
Le concept de tendance
}

\section{(2) OpenEdition}

1 Journals

Édition électronique

URL : https://journals.openedition.org/tc/627

DOI : $10.4000 /$ tc. 627

ISSN : 1952-420X

Éditeur

Éditions de l'EHESS

\section{Édition imprimée}

Date de publication : 1 septembre 1994

ISSN : 0248-6016

Référence électronique

"Le concept de tendance», Techniques \& Culture [En ligne], 21 | 1994, mis en ligne le 30 décembre 2005, consulté le 29 septembre 2022. URL : http://journals.openedition.org/tc/627 ; DOI : https:// doi.org/10.4000/tc.627

Ce document a été généré automatiquement le 29 septembre 2022.

Tous droits réservés 


\section{Le concept de tendance}

